direct cost calculations, and some administrative expenses would also have been excluded.

The universities complained bitterly, and last month HEW revised the proposals to make them a little more palatable. The proposed revisions are now under consideration in the Office of Management and Budget, and it will be several months before any formal changes, if any, are made to FMC 73-8. If any revisions are made, they will inevitably restrict the amounts which can be claimed by the universities.

There are indications, however, that some stiff criticisms of indirect research costs may break out on Capitol Hill this year. Some of the Congressmen and Senators who in the past few years have poured scorn on research projects with trivial-sounding titles and who have criticised the National Science Foundation (NSF) for its grant review procedures, are beginning to take a critical look at the increasing indirect cost rates. Thus, for example, Robert
Michel, a Republican from Illinois who was instrumental last year in blocking funds for a behavioural science project which he found distasteful, questioned the rapid escalation of indirect costs in NSF grants when the agency's budget was before Congress last year. $\mathrm{He}$ indicated that he would take a closer look at the matter this year. And George Archibald, a key staff assistant to former Representative John Conlan, NSF's chief critic in recent years, is now administrative assistant for Conlan's successor and has already begun to investigate the matter of research overheads for his new boss.

Some of the criticisms are likely to surface when a subcommittee of the House Committee on Science and Technology holds a public hearing on indirect costs on February 22. And the House Appropriations Committee is also expected to probe the matter when the budget for the National Institutes of Health is under consideration.

Few observers here are willing to predict the outcome of these various executive and legislative investigations, but one veteran science policy watcher, now working for the White House, notes that skirmishes over indirect costs have erupted at various times since the federal government became a major sponsor of academic research in the second World War and he speculated that this skirmish will follow the familiar pattern: there will be considerable argument, the federal ground rules will be tightened and the dispute will die away until the next skirmish arises.

This time, however, there is a potent combination of irritants arising from the steep increase in overhead rates, the serious financial situation of many universities, and a strong desire among fiscal conservatives in Congress to seek ways to cut the federal budget. The dispute goes to the heart of the system by which the federal government supports university research, and it is thus of considerable importance to the overall health of American science.

\title{
Taking politics out of health
}

KEEPING an eanlier pledge to "depoliticise" the National linstitutes of Health (NIH), Joseph A. Califano, the new Secretary of Health, Education and Welfare (HEW), last week paid a visit to the NIH campus to announce that the Canter Administration thas decided to retain Dr Donald S. Fredrickson as NIH Director. The announcement, delivered to a packed audience of research workers, was included in a gentle pep talk in which Califano again promised to insulate NIH from partisan politics, and gave assurances that he would personally seek more resources for biomedical research.

The announcement, and the fact that Califano went to NIH to deliver it, should help to soothe complaints from biomedical researchers that NIH has been subjected to unwelcome political pressure in recent years. During the Nixon Administration, for example, candidates for NIH advisory committees were screened for their political affiliations, and two NIH directors have recently been fired, reportedly for political reasons. The first, Dr Robert Q. Marston, was dismissed by Mr Nixon in January 1973 for opposing budget cuts and the elimination of some cherished training programmes, and his successor, Dr Robert S. Stone, was fired by $\mathrm{Mr}$ Ford in January 1957 for alleged administrative incompetence.

Dr Fredrickson, a well respected scientist and administrator, made known his desire to stay on as NIH
Director, but there was widespread speculation over whether the Carter Administrattion would retain him or replace him with a political appointee. In announcing the decision to keep Fredrickson as Director of $\mathrm{NIH}$, Califano said that the Administration had looked "only for excellence" and he had not asked any candidate for a post in HEW about his or her political views. Frederickson, he said, had been selected because he is "the best person to do the job that has to be done".

Although Califano's remarks went down well with his audience, he himself acknowledged that the problems which have been afflicting NIH in recent years cannot be cured simply by ending the political screening of candidates for NIH posts. NIH has been suffering from a combination of budgetary stringencies and rapidily shifiting priorities as funds have been channelled into cancer research and, to a lesser extent, heart research at the expense of some other programmes. To a large extent, those shifts in priorities have resulted from legislation which has given the National Cancer Institute a privileged political status in NIH. And there has also been a trend which has resulted in a growing proportion of NIH funds being disbursed as contracts rather than grants-a trend which has increased the central management of biomedical research, but which thas met with stiff resistance from academic scientists.
In response to some of the concerns which have been expressed in the past few years about the growing politicisation of $\mathrm{NIH}$ and the disparities in funding, Congress established a Presidential commission under the chairmanship of a former medical school dean, Franklin Murphy. The Murphy panel last year issued a number of recommendations designed to reduce the privileged status of the cancer institute and to ease the strains within NIH. The Ford Administration made no move to implement the proposals, however, and the question now is whether or not Califano will act on them.

As for funds for NIH, although they have been increasing in the past few years, they haven't kept pace with inflation. According to an analysis recently completed by NIH's budget office, for example, the proportion of research grants approved by peer-review committees which have actually been funded has declined from $58 \%$ to $35 \%$ over the past three years, and it will drop to $32 \%$ next year if $\mathrm{Mr}$ Ford's final budget proposals are implemented. Califano said, however, that "I believe the work you do here, and that basic research generally in health, is critical for our socicty and needs additional support and resources, and l'il do my best to try and get them for you".

That went down particularly well with his listeners.

Colin Norman 